REFERENCES

Anonymous (1943). Vitam. D Dig. 5, I7.

Aschaffenburg, R., Bartlett, S., Kon, S. K., Roy, J. H. B., Sears, H. J., Thompson, S. Y., Ingram, P. L., Lovell, R. \& Wood, P. C. (1953). Brit. F. Nutr. 7, 275.

Aschaffenburg, R., Bartlett, S., Kon, S. K., Roy, J. H. B., Walker, D. M., Briggs, C. \& Lovell, R. (195 I). Brit. F. Nutr. 5, 17 I.

Aschaffenburg, R., Bartlett, S., Kon, S. K., Terry, P., Thompson, S. Y., Walker, D. M., Briggs. C., Cotchin, E. \& Lovell, R. (1949). Brit. F. Nutr. 3, 187.

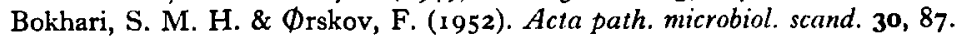

Ingram, P. L., Lovell, R., Wood, P. C., Aschaffenburg, R., Bartlett, S., Kon, S. K., Roy, J. H. B. \& Sears, H. J. (1953). Int. Dairy Congr. XI11. The Hague, 3, 1365.

Jordan, L. (1933). Vet. J. 89, 202.

Lovell, R. \& Hill, A. B. (1940). F. Dairy Res. I1, 225.

Фrskov, F. (1951). Acta path. microbiol. scand. 29, 373.

Payne, W. J. A. (1949). Brit. F. Nutr. 3, i.

Shanks, P. L. (1950). Vet. Rec. 62, 315.

Walker, D. M. (1948). Studies in nutrition of young dairy stock. Doctorate Thesis, University of Reading.

Withers, F. W. (1952a). Brit. vet. F. 108, 315 .

Withers, F. W. $(1952 b)$. Brit. vet. $\mathcal{~}$. 108, 382 .

Wood, P. C. (1955). F. Path. Bact. (In the Press.)

\title{
Energy Utilization in Overfed Thin Young Men*
}

\author{
By R. PASSMORE, A. P. MEIKLEJOHN, A. D. DEWAR \\ AND ROSEMARY K. THOW \\ Departments of Physiology and Medicine, University of Edinburgh and the \\ Metabolic Ward, Edinburgh Royal Infirmary
}

(Received 21 fune 1954)

Some people keep in good health, appear to have a good appetite and yet remain very thin. This is a commonplace observation. 'Their friends may wonder what they do with the food they eat. Yet no physiological abnormality has been demonstrated in such people. Grafe (Grafe \& Graham, 191 I; Grafe, r933) has indeed suggested that some people possess a mechanism that burns off any excess of food eaten. This luxus Konsumption mechanism might be set too high, and so might keep a person permanently thin. His experiments on both animals and patients are not generally accepted as reliable evidence for his thesis. In particular he failed to appreciate that starvation per se lowers the basal metabolic rate. Gulick (1922) in careful experiments on himself, a lean person, found that on a high caloric diet and a standard régime, he gained weight more rapidly when his initial weight was lower than usual than from a start well above his usual weight. These observations were consistent with a luxus Konsumption mechanism, but as he did not control accurately his energy expenditure, they provide no conclusive evidence. We know of no other scientific evidence to support the hypothesis. Newburgh (1950) has shown how tenuous is the support for a luxus Konsumption and himself produced evidence that there is no metabolic control by direct oxidation of a dietary excess of food.

* The work was done with the assistance of Elizabeth Mutch, Blodwen Jehu and D. Shirling. 
In any studies of energy balance, it is necessary to measure accurately weight changes, caloric intake and caloric expenditure. The last presents the chief difficulty. Newburgh has estimated the caloric expenditure of persons carrying on their usual occupations from the evaporative heat loss. The water lost by evaporation can readily be determined over $24 \mathrm{~h}$ from the invisible weight loss (the weight of food and liquid consumed minus the weight of urine and faeces plus any gain in body-weight). Newburgh contended that the evaporative heat loss is closely related to total heat loss, forming between 23 and $25 \%$ of this loss in the absence of visible sweating. He has certainly shown that this precise fractionation of heat loss occurs in some individuals; it may not be a general phenomenon. Anyway, this is a very indirect method of determining energy expenditure, and its use must cast some doubt on the validity of Newburgh's condemnation of Grafe's thesis.

The development in Germany (Kofranyi \& Michaelis, I940; Müller \& Franz, 1952) of a light portable respirometer, which directly measures the volume of the expired air and simultaneously collects a small sample for subsequent analysis, has greatly facilitated indirect calorimetry. It is now possible by means of indirect calorimetry, with a continuous record of an individual's activities, to obtain much more precise data for daily energy expenditure (Passmore, Thomson \& Warnock 1952). We therefore thought it worth while to study energy balances with this method, in relation to a possible luxus Konsumption mechanism. If such a mechanism exists it should presumably be most active and so most easily demonstrated in persons of a thin constitution when they are under a surfeit of food. Accordingly, we set out to study the metabolic changes in underweight but otherwise healthy persons, when fed with food beyond their requirements. The three underweight young men who served as subjects for these experiments were admitted to the Metabolic Ward of the Edinburgh Royal Infirmary. They were confined to bed for the greater part of the day in order to cut down their energy expenditure, to increase the excess intake of calories and to facilitate the measurements of their energy expenditure. A measured and controlled amount of exercise was permitted to prevent the physical deterioration that accompanies total confinement to bed.

\section{METHODS}

Subjects. All three were healthy young men. 'Table I shows their heights and weights, and standards for weight and basal metabolic rate which were those of Odier \& Mach (1949) and Robertson \& Reid (1952) respectively. None of the three had had any major illness in the previous 3 years.

Régime. The following daily routine was practised with only trivial departures. Each day was recorded as beginning at 8 a.m.; apart from toilet necessities the subjects stayed in bed until I. $3^{\circ}$ p.m., then got up, dressed and walked three times round 'The Meadows' outside the Royal Infirmary. 'The total distance walked was about 5 miles. A speed of about $4 \mathrm{~m}$.p.h. was maintained by constant reference to a stop-watch at fixed points on the route. There was a good surface on the pavement and the gradients were negligible. On two occasions the weather curtailed the walk, and the distance was made up on the next day. After the exercise they returned to the 
ward and remained out of bed, for the most part sitting and reading until they went to bed at about 8 p.m. Each man kept a diary in which was recorded to the minute each day, the time spent in bed, walking, sitting and in 'other activities', which

Table 1. The subjects

\begin{tabular}{|c|c|c|c|c|c|}
\hline & & & & ight & \\
\hline Name & Age & $\begin{array}{l}\text { Height } \\
\text { (cm) }\end{array}$ & $\begin{array}{c}\text { Initial } \\
(\mathbf{k g})\end{array}$ & $\begin{array}{l}\text { As percentage } \\
\text { of standard } \\
\text { weight } \\
\text { (Odier \& Mach, } \\
\text { I949) }\end{array}$ & $\begin{array}{c}\text { Standard } \\
\text { B.M.R. } \\
\text { (Cal./min) } \\
\text { (Robertson \& } \\
\text { Reid, r952) }\end{array}$ \\
\hline David & 22 & 180 & $61 \cdot 83$ & 85 & $I \cdot 12$ \\
\hline Michael & 21 & 180 & $59 \cdot 15$ & 82 & $\mathrm{I} \cdot 10$ \\
\hline Sam & 24 & 172 & 57.00 & 86 & 1.03 \\
\hline
\end{tabular}

included washing, dressing and toilet. David was in the hospital for 15 days ( 5 control and ro excess feeding) in September. Michael and Sam were in for 18 days ( 4 control and I $_{4}$ excess) in March.

Diet. The pattern of the diet was unchanged throughout. There were four main meals-breakfast at 8.30 a.m., lunch at 12.30 p.m., tea at 3.30 p.m. and supper at 7.0 p.m. In addition there was a cup of tea with milk in the early morning, a drink of Bovril or Horlicks at I I a.m. and an evening drink of cocoa or milk at Io p.m. An exact replica of each meal was weighed out and brought to the laboratory for analysis. During the control period a diet containing about $2300 \mathrm{Cal}$./day was given; this was increased up to nearly $4000 \mathrm{Cal}$./day during the period of overfeeding. None of the subjects had any great difficulty in eating this excess.

Indirect calorimetry. Oxygen consumption was measured at 4 -hourly intervals throughout the day and night: at about I I a.m., I I p.m., 3 a.m. and 7 a.m. when the subjects were in bed, at 3 p.m. during the walk and at 6 p.m. when sitting reading in the ward. No attempt was made to take the samples punctually, or to standardize behaviour either before or during the sampling. If the subject happened to be reading, he continued with it. All samples were taken over a 10 min period (except 5 min for walking). In this way it was hoped to get a representative picture of oxygen consumption throughout the $24 \mathrm{~h}$. Samples were collected on all the control days and on 6 of the ro days of overfeeding for David and on 8 of the 14 days of overfeeding for Michael and Sam.

The volume of the expired air was measured, and a continuous sample collected for analysis, with the Kofranyi-Michaelis respirometer (Kofranyi \& Michaelis, 1940; Müller \& Franz, 1952).

Gas analysis was done in duplicate with the Haldane gas-analysis apparatus.

Dietary analyses. Each day's food and liquid were collected, weighed, homogenized in an electric blender, poured into a single large jar and thoroughly stirred. A portion was then set aside in a deep-freeze refrigerator for subsequent analysis.

Faeces. Each day's accumulation of faeces was weighed and then transferred to a jar in the deep-freeze refrigerator. Each subject's faeces were pooled for the whole control period and during the excess feeding in 3 - to 7 -day lots. 
Urine. $24 \mathrm{~h}$ accumulations were measured, and a sample of about $300 \mathrm{ml}$. was preserved with a pinch of mercuric chloride in a refrigerator.

Bomb calorimeter. The net caloric value of the food was determined from the heats of combustion of the food and faeces measured in a bomb calorimeter (Atwater \& Snell, 1903). The heat of combustion of the urine was calculated using the factor of 8.09 Cal./g urinary nitrogen (Benedict \& Milner, 1907).

Nitrogen estimations. Nitrogen was determined in the food, faeces and urine by the micro-Kjeldahl method.

\section{RESULTS}

Energy expenditure. Table 2 gives the mean rates of energy expenditure at 4 -hourly intervals for all three subjects. Fig. I shows, on a scatter diagram, all the observations made on David. Table 3 gives the calculated mean daily energy expenditure of all three subjects on the balanced and on the excess diets. It will be seen that there were

Table 2. Rate of energy expenditure (Cal./min) of thin young men on a balanced diet and during overfeeding

\begin{tabular}{|c|c|c|c|c|c|c|c|}
\hline Subject & Diet & $\begin{array}{l}\text { I I a.m. } \\
\text { (in bed) }\end{array}$ & $\begin{array}{c}\text { 3 p.m. } \\
\text { (walking at } \\
4 \text { m.p.h.) }\end{array}$ & $\begin{array}{l}7 \text { p.m. } \\
\text { (sitting } \\
\text { reading) }\end{array}$ & $\begin{array}{l}\text { I I p.m. } \\
\text { (in bed) }\end{array}$ & $\begin{array}{l}3 \text { a.m. } \\
\text { (in bed) }\end{array}$ & $\begin{array}{c}7 \text { a.m. } \\
\text { (in bed) }\end{array}$ \\
\hline \multirow[t]{2}{*}{ David } & Balanced & $I \cdot 50$ & 5.5 & $1 \cdot 50$ & $I \cdot I 6$ & I.09 & $I \cdot 23$ \\
\hline & Excess & $1 \cdot 48$ & $5 \cdot 6$ & $\times 67$ & $I \cdot 21$ & $1 \cdot 09$ & $1=26$ \\
\hline \multirow{2}{*}{ Michael } & Balanced & $I \cdot 32$ & 47 & $I \cdot 26$ & $I \cdot 12$ & I.06 & I.08 \\
\hline & Excess & $1 \cdot 55$ & $4 \cdot 6$ & $1 \cdot 50$ & $I \cdot 29$ & $I \cdot 10$ & $I \cdot 12$ \\
\hline \multirow[t]{2}{*}{ Sam } & Balanced & $1 \cdot 34$ & 5.0 & $I \cdot 38$ & I.04 & 0.89 & $1 \cdot 12$ \\
\hline & Excess & 1.47 & $5 \cdot 0$ & 1.60 & $1 \cdot 14$ & I.09 & $x \cdot 24$ \\
\hline
\end{tabular}

Table 3. Calculated mean daily energy expenditure of thin young men on a balanced diet and during overfeeding

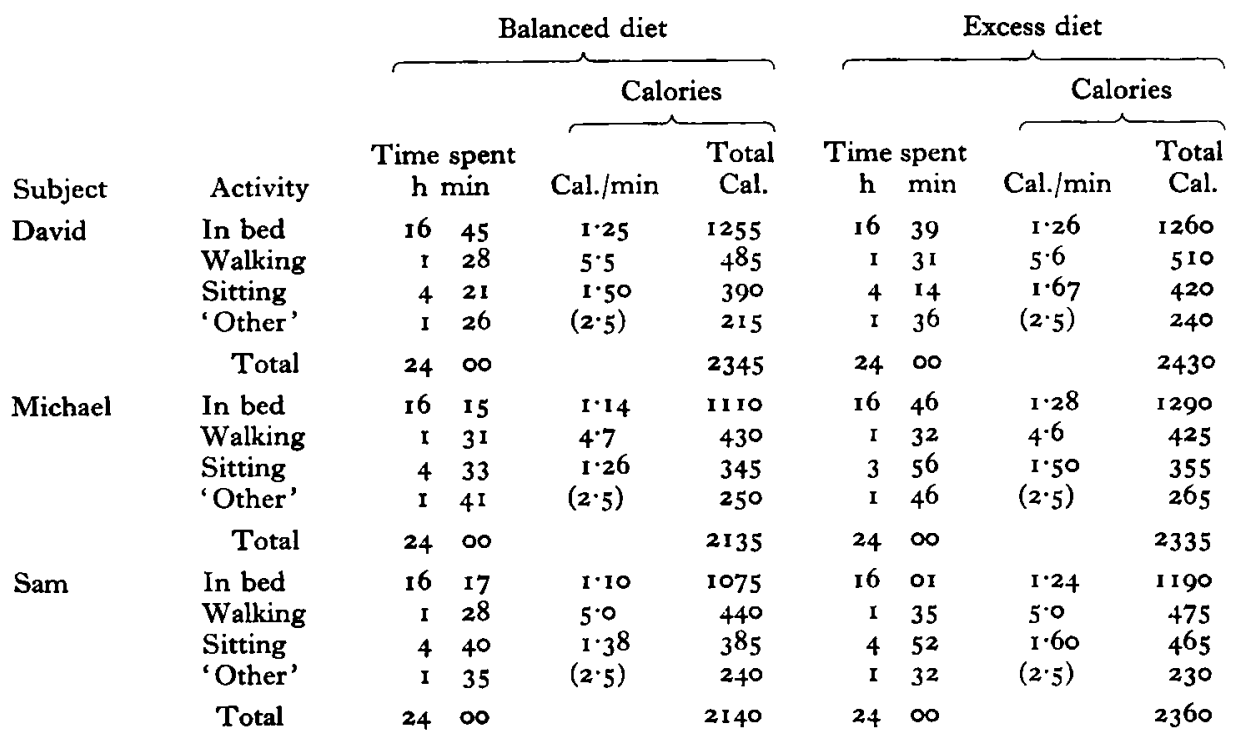


only minor variations in the times spent by the men in their various activities. The figure used for calculating energy expenditure in bed is the average of all observations taken at I I a.m., I I p.m., 3 a.m. and 7 a.m. It represents a fair average for all the time spent in bed by each subject. The figure $2.5 \mathrm{Cal} . / \mathrm{min}$ used to calculate the cost of 'other' activities is admittedly a guess. In making it we have been helped by direct measurements of the cost in energy of various personal and domestic activities made

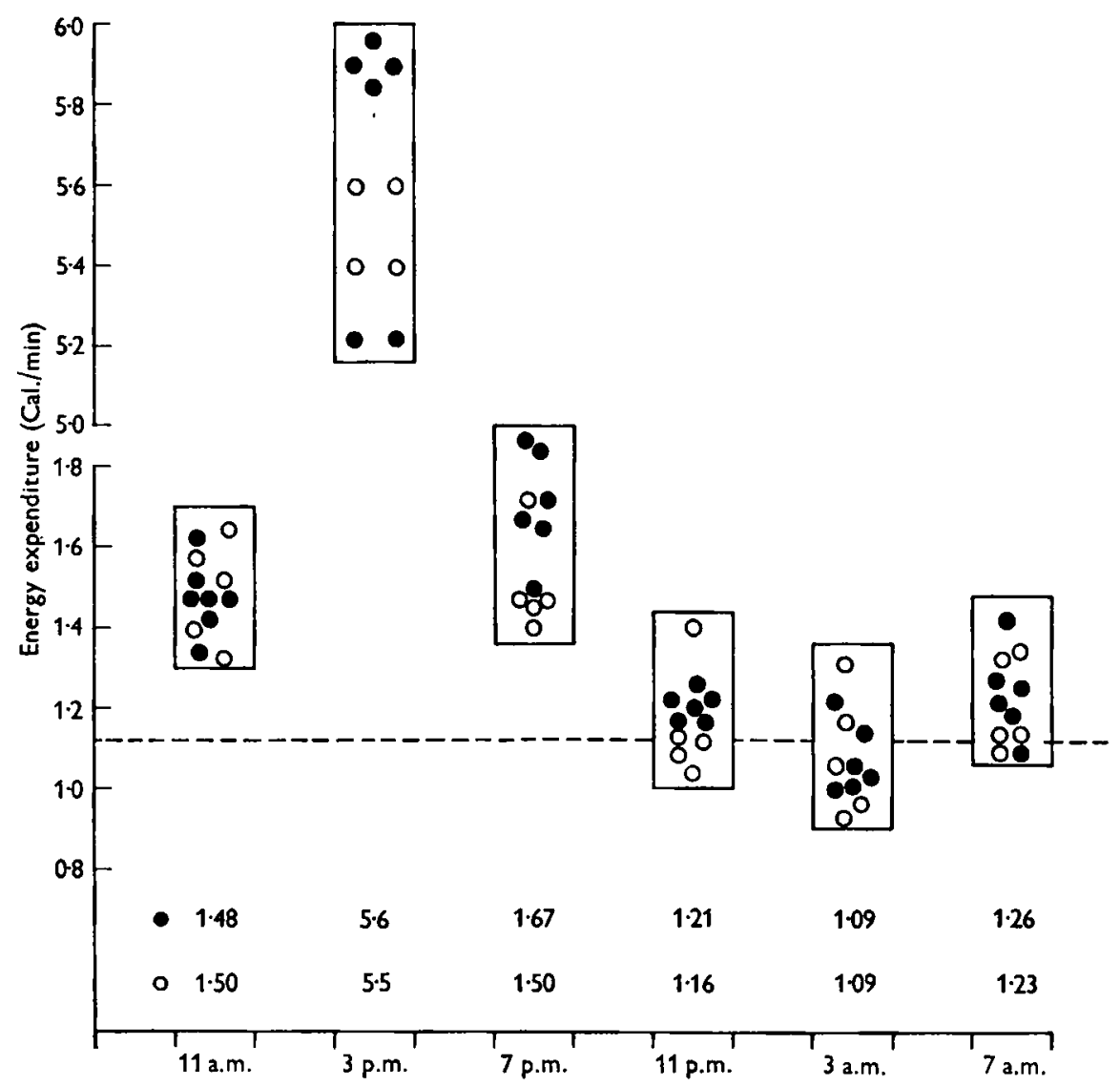

Fig. I. Scatter diagram of all measurements of rates of energy expenditure made on David. $O$, measurements when he was on a balanced diet; - , measurements during overfeeding. Mean values are given at the bottom of the figure. Dotted line indicates standard B.M.R. (Robertson \& Reid, 1952).

on other subjects. Even should it be in error by as much as $20 \%(0.5 \mathrm{Cal}$.), which is most unlikely, so little of the total time is involved that the gross error would be less than 50 Cal./day. 'Table 3 shows that during the period of excess energy intake, daily caloric expenditure rose by 85,150 and $225 \mathrm{Cal}$. for the three subjects. This represents an amount varying from 6 to $16 \%$ of the excess intake. It is impossible to attribute this increase to any luxus Konsumption mechanism. The increase can probably be accounted for as the specific dynamic action of the excess protein. Protein intake rose from 79 to $131 \mathrm{~g} /$ day for David and from 77 to $124 \mathrm{~g} /$ day for the other two. The increases in metabolism were somewhat less than might be expected to follow upon 
the ingestion of $47-52 \mathrm{~g}$ extra protein daily. Table 2 and Fig. I show that by II p.m. metabolism was approaching basal levels, even on the excess diet. It was down to basal levels in the early hours of the morning. Both David and Sam gave results appreciably above predicted levels for basal metabolism at 7 a.m.; but conditions were not strictly basal then as they had usually taken a cup of tea with milk.

Both on the balanced and the excess diet these figures for energy expenditure are precisely what might have been predicted from classical physiology. There is no shred of evidence to suggest that the thinness of these three young men is due to any inherent ability to oxidize surplus food. None of the three gave any sign of reacting to the dietary excess by a luxus Konsumption mechanism.

Alimentary absorption. Table 4 shows the weights of faeces passed and the analyses of some of the constituents. The values for caloric content were determined directly in a bomb calorimeter. Averaging the figures for faecal nitrogen excreted by David

Table 4. Mean daily composition of faeces excreted by thin young men on a balanced diet and during overfeeding

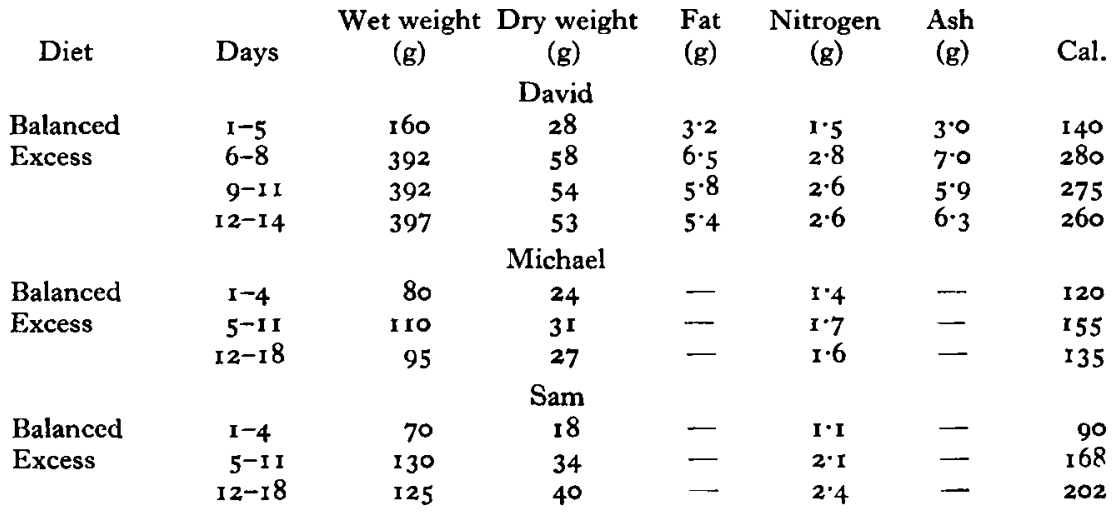

and comparing them with nitrogen intake show that $88 \%$ of the nitrogen was absorbed during the control period and $87 \%$ during the excess feeding. The corresponding percentages for fat are 97 and 96 and for calories 94 and 93 . These figures show normal absorption. Michael and Sam show even smaller losses in the faeces. Clearly not one of these young men was thin on account of a failure of his alimentary canal to absorb his food.

\section{DISCUSSION}

The validity of our claim that there was no luxus Konsumption mechanism in these subjects depends on the reliability of the estimations of energy expenditure by indirect calorimetry over a $24 \mathrm{~h}$ period. During the control period there was a check on energy expenditure, so determined, against dietary intake and weight changes, as set out in Table 5. The general agreement would appear to justify the claim.

Table 6 sets out the corresponding data during the excess feeding. The gain in weight was less than might be expected from the surplus of food. An analysis of the weight gain has led us to give a possible explanation of this. The analysis, however, 
rests on a large number of theoretical considerations and the final conclusions can only be tentative. As it contrasts with the clear-cut, measured observation that the excess food was almost fully absorbed and only a small proportion oxidized, we prefer to leave this analysis for consideration in another paper (Passmore, Meiklejohn, Dewar \& Thow, 1955).

Table 5. Mean daily intake and expenditure of energy and weight changes in thin young men whilst receiving a balanced diet

$\begin{array}{lccc} & \text { David } & \text { Michael } & \text { Sam } \\ \text { Caloric intake (net) (Cal.) } & 2100 & 2110 & 2140 \\ \text { Caloric expenditure (Cal.) } & 2345 & 2135 & 2140 \\ \text { Weight change (g) } & -10 & - & +10\end{array}$

- Net caloric intake $=$ dietary calories - faecal and urinary calories.

Table 6. Mean daily intake and expenditure of energy and weight changes in thin young men during overfeeding

$\begin{array}{lccr} & \text { David } & \text { Michael } & \text { Sam } \\ \text { Caloric intake (net)* (Cal.) } & 3730 & 3970 & 3920 \\ \text { Caloric expenditure (Cal.) } & 2430 & 2335 & 2360 \\ \text { Difference (Cal.) } & 1300 & 1635 & 1560 \\ \text { Weight gain (g) } & 150 & 175 & 187 \\ \text { Net caloric intake = dietary calories }- \text { faecal and urinary calories. }\end{array}$

\section{SUMMARY}

I. Three constitutionally thin young men were fed on diets from 1300 to I600 Cal. in excess of requirements for periods of 10-14 days. During this time they followed a standard régime of physical activities whilst resident in the metabolic ward of a hospital.

2. Energy expenditure was determined by indirect calorimetry at 4-hourly intervals throughout $24 \mathrm{~h}$ periods.

3. There was no evidence that any of the excess food was oxidized, apart from a small amount due to the rise in metabolism attributable to the specific dynamic action of the extra protein ingested.

4. Faecal analyses showed that over $90 \%$ of the excess food was absorbed.

We have to thank Professor D. M. Dunlop for allowing us the use of three beds in his ward and for providing every facility for this study. We are grateful to David, Michael and Sam for cheerfully doing what they were told and eating what was set before them. We have to thank the Medical Research Council for a grant for expenses and a personal grant to one of us (R.K.T.).

\section{REFERENCES}

Atwater, W. O. \& Snell, J. F. (1903). J. Amer. chem. Soc. 25, 659.

Benedict, F. G. \& Milner, R. D. (1907). Bull. U.S. Off. Exp. Sta. no. 175.

Grafe, E. (1933). Metabolic Diseases and their Treatment. Philadelphia: Lea and Febiger.

Grafe, E. \& Graham, D. (IgII). Hoppe-Seyl. Z. 73, I.

Gulick, A. (1922). Amer. 7 . Physiol. 60, 371 .

Kofranyi, E. \& Michaelis, H. F. (1940). Arbeitsphysiologie, II, 148. 
Müller, E. A. \& Franz, H. (1952). Arbeitsphysiologie, 14, 499.

Newburgh, L. H. (1950). In Clinical Nutrition, p. 689. [N. Jolliffe, B. F. Tisdall and P. R. Cannon, editors.] New York: Paul B. Hoeber Inc.

Odier, J. \& Mach, R. S. (1949). Praxis, 38, 384. Quoted by McCance, R. A. \& Widdowson, E. M. (195I). Proc. roy. Soc. B, 138, 115 .

Passmore, R., Meiklejohn, A. P., Dewar, A. D. \& Thow, R. K. (1955). Brit. F. Nutr. 9, 27.

Passmore, R., Thomson, J. G. \& Warnock, G. M. (1952). Brit. F. Nutr. 6, 253.

Robertson, J. D. \& Reid, D. D. (1952). Lancet, 262, 940.

\title{
An Analysis of the Gain in Weight of Overfed Thin Young Men*
}

\author{
By R. PASSMORE, A. P. MEIKLEJOHN, A. D. DEWAR \\ AND ROSEMARY K. THOW \\ Departments of Physiology and Medicine, University of Edinburgh and the \\ Metabolic Ward, Edinburgh Royal Infirmary
}

(Received 2 I Fune 1954)

The preceding paper(Passmore, Meiklejohn, Dewar \& Thow, 1955) describes an experiment in which three thin but healthy young men were fed on more food than they needed to maintain their weight. Measurements showed that the excess food was effectively absorbed, but no more was oxidized than could be accounted for by the specific dynamic action of the extra protein consumed. In this paper it is shown that, although all three gained weight, the gain was less than expected had all the excess food gone to make 'obese tissue'. Keys \& Brožek (1953) have suggested that changes in weight of healthy people result from gain or loss of 'obese tissue', which is composed of $62 \%$ fat, $24 \%$ cell mass and $14 \%$ extracellular fluid.

It is a common belief that thin people have some mysterious means of disposing of surplus food. Since these thin men failed to gain as much weight as expected, the observations made on them offer a possible clue towards an understanding of the metabolic mechanisms which determine leanness in some people and obesity in others. Whilst a proper understanding of these mechanisms is unlikely until many more metabolic experiments have been made on human subjects, it is felt that the present observations may be found useful in planning future experiments.

A study is presented of the balances of energy, nitrogen, water, sodium and potassium, measured in these three men during overfeeding. Some inductions are made therefrom about the disposal in the body of the surplus food.

\section{METHODS}

The weights of the subjects were recorded on an old beam balance of the type used by Sanctorius (1614); it can weigh a man with an accuracy of $\pm 5 \mathrm{~g}$. The methods employed for the measurement of energy intake and output and of nitrogen balance are described in the preceding paper (Passmore et al. 1955). The methods used for

- The work was done with the assistance of Elizabeth Mutch, Blodwen Jehu and D. Shirling. 